International Journal of Social Research
(ISSN:2576-5531)

\title{
Women Empowerment for Sustainable Rural Livelihoods: Voices From Kenya
}

\section{Susan Njogu, Dr. Doris Nyokagi, Wambu Charles}

Institute of Gender, Women and Development Studies, Egerton University, P.O Box 536 Egerton

\begin{abstract}
Rural women play a critical role in the rural economies of both developed and developing countries. In most parts of the de- Wambu Charles

veloping world they participate in crop production and livestock Institute of Gender, Women and care, provide food, water and fuel for their families, and engage Development Studies, Egerton Uniin off-farm activities to diversify their families' livelihoods. In ad- versity, P.O Box 536 Egerton dition, they carry out vital reproductive functions in caring for children, older persons and the sick. To understand the situation of rural women, it is necessary to examine the full diversity of their experiences in the context of the changing rural economy, including their position within household and community structures. A multi-stage sampling method was employed to select 136 respondents. Primary data was collected through the use of questionnaires and interview schedule and were subjected to both descriptive and inferential statistics. The mean farming experience was 11.4years, while mean farm size was 1.4 ha. The main source of agricultural information was radio. Regression How to cite this article:

Susan Njogu et al.,.WOMEN EMPOWERMENT FOR SUSTAINABLE RURAL LIVELIHOODS: VOICES FROM KENYA. International Journal of Social Research, analysis showed that level of education, age and marital status were significantly related with level of participation. The findings conclude that women voices and level of participation is influenced by level of education, marital status and age. Therefore, the study recommends that women participation in sustainable livelihoods can only be achieved by empowering them with training and access to land in order to raise their voices in agricultural 2017; $1: 1$. sector.
\end{abstract}

Key words: Women empowerment, Sustainability, Rural livelihoods and Women voices 


\section{Introduction}

Most Kenyan farmers carryout agricultural production at the subsistence (small holder) level in an extensive agricultural system; despite this the country's food security and agricultural development depend on them (FAO, 2014). Particularly striking is the fact that rural women, take the lead role in agricultural activities, making up to $60-80 \%$ of labour force (FAO, 2011). It is ironical that their contributions to agriculture and sustainable rural livelihoods projects are seldom noticed. According to Ogunlela and Muktar (2009) observed that low participation by women in national and regional level policymaking affects sustainability of agricultural sector. Poor targeting of women by extension services providers suggested that access to agricultural information and policy making issues which are of most concern to women have been neglected in the design and implementation of development policies and programmes. In countries such as Benin Republic, the programmes developed were far from addressing the main concerns of women as they were neither involved in policy making decisions nor were they directly consulted to articulate their needs (World Bank 2014). According to Sabo (2016) agricultural improvement initiative which ignores the impact of women's participation in agricultural development can at best achieve 'false growth'. It is therefore necessary that agricultural policies, programmes, and projects should address women's specific issues in order to raise their voices especially in decision making process at household, local , national and regional levels.

About $75 \%$ of the poor according to a recent World Bank estimate are found in rural areas (World Bank, 2014). The main source of livelihoods in rural areas is draw from agriculture and related activities (Yemisi \& Aisha, 2009). Evidently, development, food security and poverty alleviation will not be truly achieved without rapid agricultural growth. Assisting the rural poor to achieve their livelihoods and food security in a sustainable manner is, therefore, a great challenge. Broadly, increase in agricultural productivity is central to growth, income distribution, improved food security and alleviation of poverty in rural Africa (Chale, 2010). In all these, the rural women plays pivotal and crucial roles to the overall success of efforts directed at agricultural development in rural areas. Women participation in sustainable rural livelihoods programme in Njoro sub-county depend on access to natural resources, agricultural extension information service and Technical services from various stakeholders but mainly from the ministry of agriculture (Auta, 2014). The main source of sustainable rural livelihoods for women in rural areas includes cultivation, planting, harvesting, processing farm produce, marketing and livestock keeping. Sustainable rural livelihoods projects and programmes are aimed at improving the lot of women farmers in the state by providing information on improved farming techniques and new research findings to the peasant women farmers whose roles have been overlooked for too long. By providing these services a higher production and increased income could be attained (Onyango, 2015). The Sustainable rural livelihoods projects and programmes within the existing government Agricultural Development Projects (ADPs), was created in 2003 to address the gender-related deficiencies within the existing extension programmes (NADP, 2007). The programme came about when it became obvious that in spite of a decade of World Bank's assistance in building up Kenya's agricultural sector and extension service provision, women farmers were still receiving minimal assistance and information from extension agents (Lelo, Chiuri \& Jenkins, 2006). The role played by women farmers in meeting the challenges of agricultural production and development is quite prominent. Their relevance and significance, therefore, cannot be trivialized (Roshini \& Linda, 2009).

Depending on the region, women produce two thirds of the food crops in most communities in 
Kenya (FAO, 2011). Ross (2009) observed that widespread assumption that men and not women make the key farm management decisions has prevailed. Unfortunately, women farmers in Kenya are among the voiceless, especially in agricultural management and policies formulation. In Kenya the agricultural sector has been devolved to the county governments and the national government is playing minimum roles in increasing food production and food security. Most county governments are either lacking or unwilling to invest in the capacity building in agricultural sector. This has been underestimated or totally ignored women's role in both production and the general decision-making process within the household, local and national level. According to Auta (2014), women in Kenya produce, process and market about $80 \%$ of food crops and small livestock such as poultry, manage $70 \%$ of all small scale agribusiness enterprise and about $33 \%$ of all small households which is sustained by women. Their role in agriculture has important implication for development because women constitute a very important segment of the labour needed in production. Adekanye Otitolaiye and Opaluwa (2009) reported that extension services have often been ineffective in food and agriculture. But the problem is more compounded in the case of women because of the inequality in access to natural resources such as land and agricultural extension services. In this system, men are always the first and perhaps the only target recipient of the planned change in agriculture. Available evidence shows that women still lag behind in terms of access and control of land, extension contact, accessibility to training and other indices of development education for agriculture.

FAO (2014) observed that notwithstanding the splendid achievements recorded by agriculture sector in Kenya various problems have been encountered, which include shortage of extension agents, as the ratio of extension staff to farm families is still low making it difficult to individually meet all the women farmers. In addition women participating in agricultural activities do not only require purely agriculturebased information but also entrepreneurship skills. Although women participation in sustainable rural livelihoods programme and projects has been in existence since 1989, there have been only a few systematic efforts to access its performance (Abedi, Allahyari \& Khodamoradi, 2011). The few studies that were carried out were either outside the researcher's study area or were not on the women voices and participation of the women farmers in sustainable rural livelihoods programmes and projects. Hence, information about women voices and participation in sustainable rural livelihoods programme in the study area remains scanty. It is for this reason this research was undertaken with the broad objective of analyzing the factors influencing women voices and participation in sustainable rural livelihoods programmes and projects in Njoro sub-county Kenya. The specific objectives of the study were to:

1. Describe the demographic and socioeconomic characteristics of women participating in sustainable rural livelihoods in the study area.

2. Describe the sources of the agricultural information of the women participating in sustainable rural livelihoods in the study area.

3. Assess the level of participation of women participating in sustainable rural livelihoods in the study area.

4. Determine the socio-economic factors influencing women's' level of participation in women participating in sustainable rural livelihoods in the study area.

5. Determine the institutional factors influencing women's' level of participation in sustainable rural livelihoods in the study area.

6. Identify the challenges faced by women participating in sustainable rural livelihoods in the study area.

\section{Methodology}

This study was carried out in Njoro sub-county. Njoro sub-county is located in the greater Http://escipub.com/international-journal-of-social-research/ 0003 
Nakuru County on the eastern edge of the Mau Forest Complex, the largest single forest block in Kenya. The area lies between the forest and Lake Nakuru National Park, a world famous flamingo habitat. Njoro sub-county is situated

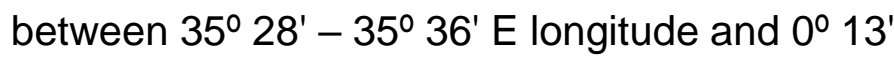
$-1010^{\prime} \mathrm{S}$ latitude. It also stands at an altitude of $1,800 \mathrm{~m} \quad(6,000 \mathrm{ft})$ above sea level. Temperatures range between $17-22^{\circ} \mathrm{C}$, while the average annual rainfall is in the region of $1,000 \mathrm{~mm}$. The sub-county has five administrative divisions (Njoro, Lare, Kihingo Mauche and Mau-Narok). In 2009, the population of Njoro Division was 87,489 . The estimate for 2017, using a growth rate of $2 \%$ per year, is 96,595 (National Population Commission, 2012). The main livelihoods of the people of Njoro sub-county are saw-milling, cattle-keeping and crop farming. In the past, the land was covered with forests but due to the expansion of agriculture and the general population growth, these have receded. The primary occupation of most households in Njoro sub-coumty is crop farming and livestock production. Other major occupations that form sizeable proportions of households income is value addition of farm produce and trading (Auta, 2014). A multi stage sampling method was employed for the selection of respondents. Firstly, two zones were identified horticultural crops producing zones (Mauche and Maunarok) and cereal crops and livestock production zones (Njoro, Lare and Kihingo) out of the five administrative zones in Njoro subcounty were purposively selected, each zone representing $50 \%$ of women in groups dealing with sustainable rural livelihoods activities. Secondly, from each selected zone, two agricultural extension officers were randomly selected, representing $40 \%$. The selected blocks were Njoro, Lare, Kihingo Mauche and Mau-Narok. Thirdly, $10 \%$ of registered women groups dealing with agricultural related sustainable livelihoods activities were selected. From which group members or participants were randomly selected from each block to obtain a sample size of 136 respondents. Primary data was collected from individual group members and extension workers. The primary data was collected using structured questionnaires and interview schedule with the help of trained enumerators. Data collected was subjected to both descriptive and inferential statistics with the help of Statistical Package for Social Science (SPSS). Inferential statistics was done using regression.

\section{Linear Régression}

$Y=\beta 0+\beta 1 X 1+\beta 2 X 2+\beta 3 X 3+\beta 4 X 4+\ldots \ldots . .+$ $\beta 11 X 11+U$ :Equation 1

\section{Double log Régression}

$\log Y=\beta 0+\beta 1 \log X 1+\beta 2 \log X 2+\beta 3 \log X 3+$ $\beta 4 \log X 4+\ldots . .+\beta 11 \log X 11+U$ :Equation 2

\section{Semi log Régression}

$Y=\beta 0+\beta 1 \log X 1+\beta 2 \log X 2+\beta 3 \log X 3+$ $\beta 4 \log X 4++\ldots \ldots . .+\beta 11 \log X 11+U$ : Equation 3 Where:Y= Level of Participation of women farmers in sustainable livelihoods programmes, measured by the number of programmes involved in.

$\mathrm{X} 1$ = Age of farmer in years

X2 $=$ Marital Status (Married 3,

Divorced/Widow-2, Single 1)

$\mathrm{X} 3=$ Household size (.number of members)

$X 4=$ Education Level of the farmer (in years)

$\mathrm{X} 5=$ Farming experience (in years)

$X 6=$ Farm size (in hectares)

$\mathrm{X} 7 \mathrm{=}$ Access to extension (number of extension visits)

$\mathrm{X} 8=$ Access to land (Yes or No)

$X 9=$ Access to credit (in Kenya shillings)

\section{Level of Participation of Women Farmers in Sustainable Rural Livelihoods}

This is the involvement of participants in various agricultural activities such as crop production, animal production, produce marketing, food processing, bee keeping and fish farming. This was measured by the total number of agricultural activities or programmes the participants were engaged in during the farming season under study. Hence one (1) Http://escipub.com/international-journal-of-social-research/ 
point was allotted to a respondent participating in one (1) programme only, and six points (6) were allotted to the respondents engaged in all six (6) programmes.

\section{Results and Discussion}

\section{Socioeconomic} Respondents

Table 1 shows that majority (41.2\%) of respondents were between the age group of 31 to 40 years while mean age of participants was 39 years. Majority of participants $(78 \%)$ were married. About $66 \%$ of the participants had primary education and below. Majority of the participants $(67.6 \%)$ had farming experience of between 12 to 21 years. The mean farming experience was 11.4- years for participants. About $65 \%$ of participants cultivated land areas of between 1.0 and 3.0 hectares. The mean farm size by participants was 1.4 ha.

Table 1. Socio-economic Characteristics of the Respondents .

\begin{tabular}{|c|c|c|}
\hline Variables & Frequency & Percentage \\
\hline \multicolumn{3}{|l|}{ Age (Years) } \\
\hline $20-30$ & 10 & 7.35 \\
\hline $31-40$ & 56 & 41.2 \\
\hline $41-50$ & 46 & 33.8 \\
\hline $51-60$ & 14 & 10.3 \\
\hline $61-70$ & 10 & 7.35 \\
\hline Mean & 39.0 & \\
\hline \multicolumn{3}{|l|}{ Marital Status } \\
\hline Single & 5 & 3.67 \\
\hline Married & 106 & 77.9 \\
\hline Widowed & 17 & 12.5 \\
\hline Divorced & 8 & 5.88 \\
\hline \multicolumn{3}{|l|}{ Household size } \\
\hline $2-4$ & 4 & 2.9 \\
\hline $5-7$ & 50 & 36.8 \\
\hline $8-1$ & 73 & 53.7 \\
\hline $11-13$ & 9 & 6.6 \\
\hline mean & 8.5 & \\
\hline \multicolumn{3}{|l|}{ Level of education } \\
\hline No. formal education & 40 & 29.4 \\
\hline Primary education & 50 & 36.8 \\
\hline Secondary education & 14 & 10.3 \\
\hline Tertiary college education & 18 & 13.2 \\
\hline University education & 5 & 3.6 \\
\hline \multicolumn{3}{|c|}{ Farming experience (Years) } \\
\hline $2-6$ & 17 & 12.5 \\
\hline $7-11$ & 27 & 19.9 \\
\hline $12-16$ & 38 & 27.9 \\
\hline $17-21$ & 54 & 39.7 \\
\hline mean & 11.4 & \\
\hline \multicolumn{3}{|l|}{ Farm size } \\
\hline$<1$ & 40 & 29.4 \\
\hline $1-3$ & 88 & 64.7 \\
\hline$>3$ & 8 & 5.9 \\
\hline mean & 1.4 & \\
\hline
\end{tabular}


Age is a key factor in decision making as it influences participation in economic activities. Also it influences independent decision making as individuals who are above 30 years are considered mature by the society. Marital status had an impact with decision making. Women who are married are unable to make independent decisions as they rely on their husband for advice. Divorced, widowed and single women are able to make their own decisions independently. From the study results women had low level of education. This implies that the women lacked adequate knowledge which is significant factor in contributing to agribusiness growth. Lack of sufficient education and training for women is an impediment to women participation in agribusiness activities.

Sources of Agricultural Information among the Respondents
Table 2 shows that $(27.7 \%)$ of the participants indicated that radio was the most important source of agricultural information. This was followed by contact farmers (24.4\%) and television (20.9\%). The source of Radio was the most popular source of agricultural information among the respondents this was in agreement with the findings of Abedi, Allahyari and Khodamoradi (2011) who reported that $100 \%$ of Oyo women possess radio and obtained their information through radio. Use of radio by the women farmers as the most popular source of agricultural information, all the related information would be made available to them even without electricity, thereby making use of the cheap dry cell batteries as a source of power. The least popular source of agricultural information among the participants was the internet selected by $3.5 \%$.

\section{Table 2. Major Sources of Agricultural Information among the Respondents.}

\begin{tabular}{lll}
\hline Sources of information & Frequency & percentage \\
\hline Radio & 134 & 27.7 \\
Contact farmers & 118 & 24.4 \\
Television & 101 & 20.9 \\
Extension publications & 50 & 10.3 \\
Extension agents & 38 & 7.8 \\
Workshops & 26 & 5.4 \\
Internet & 17 & 3.5 \\
\hline
\end{tabular}

Use of radio by the women farmers as the most popular source of agricultural information, all the related information would be made available to them even without electricity, thereby making use of the cheap dry cell batteries as a source of power. The least popular source of agricultural information among the participants was the internet source selected by $3.5 \%$, The reason why modern sources of information may be due to the fact that majority of the women respondents had low levels of education which hinders embracing of modern sources of information.

Level of Participation of Women in Sustainable Livelihoods Enterprises
Table 3 shows that $38 \%$ of the participants were involved in 3 enterprises, while $30 \%$ participated in 2 enterprises. This implies that about $68 \%$ of respondents participated in at least 2 farming enterprises in each season. The result of the data collected also indicated that all participants $(100 \%)$ cultivated food crops ranging from maize, beans, garden peas, Irish potatoes, sorghum, sweet potato, and tomatoes, while all participants reared one or two types of livestock. The most reared type of livestock include; poultry, goats, sheep, cattle and pig. Majority of the participants were engaged in poultry goats, sheep, and cattle these respondents were mostly regarded as the 'elite' farmers. The 
participants indicated that the cultivation of maize and bean, served as special savings and a source of capital which they usually sell them along with small ruminant animals to raise capital for the next farming season. The reasons according to the respondents were due to their perception that these crops were resistant to attack by storage pests.

\section{Table 3. Distribution of Participants by their Level of Participation in Sustainable Rural Livelihoods Enterprise.}

\begin{tabular}{lll}
\hline $\begin{array}{l}\text { Number of } \\
\text { enterprise participation }\end{array}$ & Frequency & percentage \\
\hline 6 & 1 & 2 \\
4 & 12 & 24 \\
3 & 19 & 38 \\
2 & 15 & 30 \\
1 & 3 & 6 \\
Totals & 50 & 100 \\
\hline
\end{tabular}

\section{Socio-economic Factors Influencing} Women's' Level of Participation in Sustainable Rural Livelihoods Enterprises

Multiple regression analysis of the data indicated in Table 4 show that three of the variables were significantly related to level of participation of women farmers in sustainable rural livelihoods. The variables were education, age and marital status. Age and education were significantly related to level of participation at $5 \%$ and $1 \%$ level of significance respectively. This means that women's age and level of education were significantly, related to level of participation in sustainable rural livelihoods. This is plausible because older farmers would tend to stick to farming, reflecting their age-old occupation and would work hard to improve on their output. Any new agricultural programme that would bring this improvement, the farmer would like to be associated with it and would have greater desire to participate in it. With regards to education level, the negative coefficient $(-0.064)$ implies that as level of education increases, level of participation in sustainable rural livelihoods decreases which is expected. The higher the educational level of the farmer, the higher the chances of getting better paying jobs or the higher the tendency to be involved in politics and less increased participation in sustainable rural livelihoods. In general, this study re-affirms the position of many other studies, including that of African Capacity Building Foundation (2012) who identified age and educational level as factors affecting women participation in urban agriculture.

The coefficient of marital status was positive and significant at $5 \%$ level of significance suggesting that women's marital status influence their level of participation in sustainable rural livelihoods. Most of the successful sustainable rural livelihoods participants indicated that they have a good understanding, support and encouragement from their husbands in terms of advice and funding. This could have stimulated such farmers to increase their level of participation in sustainable rural livelihoods. This study is in agreement with that reported by Sabo (2016) who indicated that there is significant relationship between marital status and participation in sustainable rural livelihoods in Kenya agricultural sector. Coefficients of household size, farming experience and farm size were however not significant with level of participation. One possible explanation with regards to household size for this relationship with level of participation might be that most of the participants now discourage the over reliance on family labour on the farm to enable 
their children have access to formal education. In the case of farming experience, it might be that most of the experienced farmers tend to invest their resources and incomes into other ventures instead of increasing their level of participation in sustainable rural livelihoods.

\section{Table 4. Multiple Regression Estimates of Socio-Economic and Institutional Determinants of Women level of Participation in Sustainable Rural Livelihoods.}

\begin{tabular}{|c|c|c|c|}
\hline Variable & Coefficient & Standard error & Significance \\
\hline Age of farmers & $0.033^{* *}$ & 0.009 & 0.001 \\
\hline Marital status & 0.642 ** & 0.211 & 0.003 \\
\hline Household size & $0.009 \mathrm{NS}$ & 0.011 & 0.413 \\
\hline Level of education & -0.064 * & 0.016 & 0.000 \\
\hline Farming experience & $0.013 \mathrm{NS}$ & 0.014 & 0.375 \\
\hline Farm size & $0.182 \mathrm{NS}$ & 0.186 & 0.329 \\
\hline Extension contact & $0.203^{* * *}$ & 0.107 & 0.059 \\
\hline Access to land & $0.065 \mathrm{NS}$ & 0.506 & 0.897 \\
\hline Access to credit & $0.223 \mathrm{NS}$ & 0.284 & 0.434 \\
\hline Membership of cooperative & $0.582 \mathrm{NS}$ & 0.500 & 0.247 \\
\hline Access to market & $0.133^{*}$ & 0.025 & 0.000 \\
\hline \multicolumn{4}{|c|}{$\mathrm{R} 2=0.611$} \\
\hline$=$ Significant at $5 \%$ & \multicolumn{2}{|c|}{ Adjusted R2 = 0.566} & \\
\hline$* \star *$ Significant at $10 \%$ & \multicolumn{2}{|c|}{$\mathrm{F}-$ ratio $=13.57 \mathrm{NS}=$ Not Significant } & \\
\hline
\end{tabular}

Institutional Factors Influencing Women's' Level of Participation in Sustainable Rural Livelihoods

As indicated in Table 4 the coefficients of extension contact and that of access to market were significant and positive. Access to market was statistically significant at $1 \%$ level of significance. This means that the more access to market by the respondents the more their involvement in sustainable rural livelihoods. Informal discussion with participants during the survey revealed that most of the participants have turned out to be marketers. They bought farm produce from other farmers and carry them to other markets, thus making markets accessible to the participants. Extension contact was significant at $10 \%$ level. It was not surprising that extension contact was a good predictor of participation, given the important role being played by contact farmers in the study area under the Training and Visit (T\&V) system of extension and the replacement of most male extension agents with females. This is in agreement with the study of Ogunbameru, etal (2016) who inferred that although majority of the respondents $(70.6 \%)$ indicated they belonged to "associations", it was clear from the interview that these were mainly socio-cultural and religious groups and not really agricultural production or farm interest based associations or cooperatives that would have a positive input in their farming activities. The coefficient of multiple determinations (R2) was 0.611. The adjusted R2 was 0.566 , this means that $56.6 \%$ of the variations in women's level of participation in sustainable rural livelihoods was due to socioeconomic and institutional variables considered in the model. The F-ratio was 13.5 and statistically significant at $1 \%$. 
Similarly, Ogunbameru et al. (2016) identified extension contact, access to market, level of education, access to credit, access to land and taking part in decision making as the factors affecting women participation in urban agriculture. The coefficients of accessibility to land, access to credit and membership of cooperative were however not significant. Possible explanations to these relationships might be. The implication is that they do not influence women participation in sustainable rural livelihoods enterprises probably because they have access to them. As a result of the small sizes of cultivated lands, most respondents were not interested in obtaining credit for farming. In the last resort, they sell off their stored maize, beans and ruminant animals to raise capital for the next farming season, as most respondents indicated. Also, most of the respondents in the study area belonged to at least two cooperative associations.

\section{Challenges Facing Women Participating in Sustainable Rural Livelihoods Enterprises}

Table 5 shows that participants indicated that discrimination against women farmers in the distribution of farm inputs such as fertilizers as their major problem with a mean of 5.14. High rate of illiteracy posed the second greatest challenge with a mean of 4.32 . Other challenges include inadequate access to land with a mean of 4.21 , inadequate capital 4.12 , inadequate extension agents 2.81 lack of adequate storage facilities 2.56, and lack of market 1.81 . According to Ogunbameru at el. (2016) factors such as access to credit, land and other agricultural inputs as militating against active participation of women in sustainable rural livelihoods.

\section{Table 5. Responses on Challenges Facing Women Participating in Sustainable Rural} Livelihoods Enterprise.

\begin{tabular}{lllllll}
\hline Challenges & $\begin{array}{l}\text { Strongly } \\
\text { agree }\end{array}$ & Agree & Neutral & disagree & $\begin{array}{l}\text { Strongly } \\
\text { disagree }\end{array}$ & Mean \\
$\begin{array}{l}\text { 1. Discrimination against women farmers in } \\
\text { the distribution of farm inputs such as }\end{array}$ & $69(50.7)$ & $14(10.4)$ & $8(5.9)$ & $26(19.1)$ & $19(13.9)$ & 5.14 \\
fertilizers. & & & & & & \\
2. Inadequate extension agents & $87(63.97)$ & $23(16.91)$ & $2(1.47)$ & $21(15.44)$ & $5(3.68)$ & 2.81 \\
3. Inadequate capital & $91(66.91)$ & $25(18.38)$ & $1(0.74)$ & $9(6.62)$ & $10(7.35)$ & 4.12 \\
4. Lack of adequate storage facilities & $19(13.97)$ & $26(19.11)$ & $3(2.20)$ & $37(27.21)$ & $51(37.5)$ & 2.56 \\
5. High rate of illiteracy & $78(57.35)$ & $34(25)$ & $0(0.0)$ & $21(15.44)$ & $3(2.21)$ & 4.32 \\
6. Lack of market & $65(47.8)$ & $37(27.21)$ & $2(1.47)$ & $11(8.08)$ & $21(15.44)$ & 1.82 \\
7. Inadequate land & $93(68.38)$ & $26(19.12)$ & $0(0.0)$ & $8(5.88)$ & $9(6.62)$ & 4.21 \\
\hline
\end{tabular}

Figures in parentheses are in percentages.

\section{Conclusion and Recommendations}

The study was carried out to determine the level of participation of women in sustainable rural livelihoods enterprise. Women age, level of education and marital status played a greater role in decision making in rural livelihoods enterprises. Radio was the main source of agriculture information among rural women farmers. Contact farmers were the second main source of agricultural information. Regression analysis showed that level of education, age and marital status were significantly related to level of participation at $5 \%$ level of significance. As a result of the impressive performance by the participants in agricultural related enterprises, it was recommended that the sustainable rural livelihoods be retained and encouraged as a means of empowering women. Women should also diversify their enterprise to be more than two in order to reduce risks and uncertainty 
related to agricultural production. Based on the findings of this study, the following recommendations are hereby made.

1. With the increased confidence that women famers have in their contact farmers, more successful farmers in agribusiness should be identified, selected and trained to act as contact farmers. They should be motivated by extension agents to deliver the extension messages to other women farmers promptly.

2. .Efforts should be intensified to take functional literacy campaign for women farmers in the study area

3. Women participating in rural livelihoods enterprise which are operated in informal groups or cooperative groups/association basis, such groups should be re-organized and targeted in empowering women farmers by ensuring that necessary inputs such as fertilizers, labour saving devices such as tractor hiring services, credit facilities, good seeds, weed and pest control facilities are channeled to the women farmers directly through their associations.

4. Discrimination against women in the distribution of farm inputs was one of the major challenges facing the women farmers. Therefore there is the need for a paradigm shift - a complete re-orientation in development and efforts should be made to enhance the importance of gender as an effective instrument for policy formation.

\section{Acknowledgement}

We would like to thank the ICCD for providing resources and giving as a chance to participate in their project of decent work.

\section{Reference}

Abedi, M., Allahyari, M. S. \& Khodamoradi, S. (2011). "Role of agricultural extension and

education on rural women's trends toward microcredits programs." African Journal of Business Management, 5, 15, 6579-6585.

ACBF (African Capacity Building Foundation). (2012). Africa Capacity Indicators 2012:

ACBF.
Adekanye T.O., Otitolaiye, J.O \& Opaluwa, H. (2009). Food and Agricultural Production in Kenya: Some Empirical considerations for Engendering Economic Policy for Africa Paper prepared for presentation at IAFFE conference on Feminist Economics Boston Massachusetts, USA (26th - 28th June) pp.1-20

Afolabi, M. (2008). Women as pillars of national economy in Kenya: A study of economic activities of rural women in six local government areas of Ondo State. IAFFE summer conference, International Association For Feminist Economics, Toronto, Italy, 19 June - 21 July.

Auta, S.J. (2014). Performance of Women Groups in Agricultural Activities in Njoro sub-county Unpublished Ph.D Thesis, Department of Agricultural Economics, Egerton University, Kenya.

Capacity Development for Agricultural Transformation and Food Security. Harare:

Chale, F. (2010). Strengthening agricultural extension in Kenya: A study of problems and constraints in extension strategies and methods for reaching rural women UNDP/FAO, Rome, Italy.

Food and Agriculture Organization of the United Nations (FAO) (2014): Voluntary guidelines on the responsible governance of tenure of land, fisheries and forests in the context of national food security. Rome, FAO.

Food and Agriculture Organization of the United Nations (FAO) (2011): The state of food and agriculture 2010-2011. Women in agriculture. Closing the gap for development. Rome, FAO.

Lelo, F., Chiuri, W., \& Jenkins, M. (2006). Sustainable management of rural watershed: biophysical livestock and human interactions in the river Njoro watershed. Annual report 2005-2006

NADP (2007). Njoro sub-county Agricultural Development Project Annual Report and Village Listing Survey.

National Population Commission. (2012). National Population and Housing Final Report Extraordinary Gazette Vol. 94, (23): pp. 1-6

Ogunbameru, B.O., Gwari M.M., Idrisa Y.L., Ani, A.O., \&Yero, A.B. (2016). Empowerment of Women through Urban Agricultural Development in Maiduguri metropolitan, Borno State. Proceedings, 11th Annual Conference (AESON) 3rd - 6th April, p. 149.

Ogunlela Y.A \& Muktar A. (2009). Gender issues in agriculture and rural development in Kenya: The Role of Women. Humanit. Soc. Sci. J. Vol. 4. (1): pp.19-30.

Onyango, P. (2012). Constitutional change empowers women in politics in Kenya. Retrieved from http://www.africagoodnews.com 
Roshini, K. N., \& Linda, S. P. (2009). "Motivating factors and facilitating conditions explaining women's participation in co-management of Srilankan forests". Forest policy and economics, 11(1), 288-293. Retrieved from: www.elsevier.com.

Ross, A.C. (2009). Securing communal land rights to achieve sustainable development in Sub-saharan Africa: Critical analysis and policy implications. Journal of law, environment and development, 5(2), 130-141.

Sabo, E. (2016). Participatory Assessment of the impact of Women in Agriculture Programme of Borno State, Kenya. J. Trop. Agric. Vol. 1-2 (44):52-56.

World Bank. (2014). Kenya: Women in Agriculture. In Sharing Experiences-Examples of Participating Approach. The World Bank Group, The World Bank Participating sourcebook, Washington D.C. Retrieved July 13, 2010 from www.worldbank.org

Yemisi O. \& Aisha M. (2009). Gender Issues in Agriculture and Rural Development in Kenya: The Role of Women. Human Soc. Sci. J. Vol. 4 (1): pp. 1920 